\title{
Effectiveness of high-power diode laser associated to chemical auxiliary substance on decontamination of root canal system infected with Enterococcus faecalis - an in vitro study
}

Eficácia do laser diodo de alta potência associado com substâncias químicas auxiliares na descontaminação do sistema de canais radiculares infectados com Enterococcus faecalis - estudo in vitro

Tiago Lange dos Santos*

Matheus Albino Souza**

Alessandra Kuhn Dall' Magro*

Fabiana Vieira Vier-Peliser ${ }^{* * *}$

Luciana Ruschel dos Santos ${ }^{* * *}$

Eduardo DallMagro ${ }^{* *}$

\section{Abstract}

Objective: to evaluate the additional antibacterial action of high-power diode laser after the use of $2.5 \%$ sodium hypochlorite and $2 \%$ chlorhexidine gel in root canals infected with E.faecalis. Materials and method: 120 human teeth with single canal were inoculated with E.faecalis for 14 days and randomly divided into six groups ( $n=20)$, according to the chemical auxiliary substance used in the chemo-mechanical preparation and the use of high-power diode laser: G1( $\mathrm{NaOCl})$ - root canal preparation with $2.5 \%$ sodium hypochlorite; G2(CHX) - root canal preparation with $2 \%$ chlorhexidine gel; G3(NaOCl+DL) - root canal preparation with $2.5 \%$ sodium hypochlorite+diode laser; $G 4(C H X+D L)$ - root canal preparation with $2 \%$ chlorhexidine gel+diode laser; $G 5(\mathrm{NaCl}+\mathrm{DL})$ - root canal preparation with $0.9 \%$ saline solution+diode laser; G6(no treatment) - no treatment was performed. Microbiological test (CFUs counting) was performed to evaluate the effectiveness of proposed treatments. Data were subjected to One-way ANOVA followed by post-hoc Tukey test $(\alpha=0.05)$. Results: $\mathrm{G} 3(\mathrm{NaOCl}+\mathrm{DL})$ had reduction of $99.42 \%$ of E.faecalis, followed by $\mathrm{G} 4(\mathrm{CHX}+\mathrm{DL})-93.48 \%$; $\mathrm{G} 1(\mathrm{NaOCl})-89.82 \%$; $G 2(C H X)-81.86 \% ; G 5(\mathrm{NaCl}+\mathrm{DL})-65.40 \%$; and G6(no treatment) - no reduction. There was significant statistical difference in CFUs of all groups in relation to G6(no treatment) $(p<0.05)$. G1( $\mathrm{NaOCl}), \mathrm{G} 2(\mathrm{CHX})$, $\mathrm{G} 3(\mathrm{NaOCl}+\mathrm{DL})$ and $\mathrm{G} 4(\mathrm{CHX}+\mathrm{DL})$ were statistically superior to $\mathrm{G} 5(\mathrm{NaCl}+\mathrm{DL})(p<0,05)$. Conclusion: High-power diode laser, when associated with $2.5 \% \mathrm{NaOCl}$ or $2 \% \mathrm{CHX}$, improves the antimicrobial effect of these substances in the root canals infected with E. faecalis.

Keywords: Llaser. Sodium hypochlorite. Chlorhexidine, Enterococcus faecalis.

MSc, Department of Restorative Dentistry, School of Dentistry, University of Passo Fundo, Passo Fundo, RS, Brazil.

$\mathrm{PhD}$, Department of Restorative Dentistry, School of Dentistry, University of Passo Fundo, Passo Fundo, RS, Brazil.

PhD, Department of Endodontics, School of Dentistry, Pontifical Catholic University of Rio Grande do Sul, Porto Alegre, RS, Brazil

PhD School of Agriculture and Veterinary Medicine, University of Passo Fundo, RS, Brazil. 


\section{Introduction}

The vast majority of endodontic failures is associated with some shortcoming in the decontamination process and maintenance of microorganis$\mathrm{ms}$ in the root canal system. Literature shows that success rates of endodontic retreatments are lower than conventional root canal therapy, around $75 \%{ }^{1}$. This fact is related to some difficulties in the decontamination process, due to a distinct microbiota present in these cases.

The Enterococcus faecalis (E. faecalis) is an anaerobic facultative bacteria which grows in a biofilm structure on the root canal walls and on the depth of dentinal tubules, being capable to proliferate in either the presence or absence of oxygen ${ }^{2,3}$. This microorganism has an extra polysaccharide matrix which provides mechanical stability and decreases the action of adjuvant substances in root canal therapy $^{5,6}$. Furthermore, $E$. faecalis can survive for 10 days within dentinal tubules with no nutrient source $^{1}$ and stay viable into filled root canals until 12 months after root canal therapy ${ }^{7}$.

Thus in addition to physic and chemical modes, a different approach is necessary in order to promote an adequate decontamination of root canal system. The laser therapy arises as an auxiliary for the root canal treatment ${ }^{8-11}$. Several studies have evaluated the effectiveness of high-power lasers, such as diode laser and ErCr:YSGG, in the decontamination process of radicular dentin, showing its possible applications in endodontics ${ }^{6,8,12}$. The energy of high-power laser can be transmitted through the root canal by an optic fiber which has the ability to reach inaccessible areas of the root canal system, where endodontic instruments and chemical auxiliary substance can not properly work. Likewise, diode laser is easy to transport and may be considered a more economical alternative when compared with other high-power lasers such as Er,Cr:YSGG, $\mathrm{Nd}$ :YAG and CO2, which justifies its testing as an antimicrobial alternative in the root canal therapy.

The purpose of this study was to assess the additional antibacterial action of high-power diode laser after the use of $2.5 \%$ sodium hypochlorite and $2,0 \%$ chlorhexidine gel in root canals infected with E. faecalis.

\section{Materials and method}

This study was approved by Ethics Committee in Research of University of Passo Fundo (Passo Fundo, RS, Brazil) (protocol 229/2011).

\section{Sample obtainment and specimen preparation}

One hundred and thirty extracted human lower premolars with a single root canal were used for the present study. The teeth were stored in $4 \%$ formalin in order to preserve their properties. The dental crowns were sectioned so that all the roots had $13 \mathrm{~mm}$ in length. All roots were prepared using the same protocol in order to remove the pulp tissue and to standardize the canal diameter. The cervical third were prepared using Gates-Glidden \#3 drill (Dentsply-Maillefer, Ballaigues, Switzerland). The working length was established by introducing a K-file \#10 in the canal until its tip was visualized at the apical foramen. The working length was established by reducing $1 \mathrm{~mm}$ from this measure. The roots were prepared up to the K-file \#30 (Dentsply-Maillefer, Ballaigues, Switzerland), by serial instrumentation, using irrigation with $2.5 \%$ sodium hypochlorite (Lírio Química Ltda, São Vicente, SP, Brazil). Then, a final rinse with $17 \%$ EDTA (Iodontosul, Porto Alegre, RS, Brazil) was performed for smear layer removal. The roots were coated externally with cyanoacrylate (SuperBonder, Loctite Henkel, Itapevi, SP, Brazil), dried at room temperature for 24 hours and fixed in a plastic micro-tube of $1.5 \mathrm{~mL}$. The samples were sterilized in autoclave (Dabi Atlante, Ribeirão Preto, SP, Brazil) for a period of 30 minutes at a temperature of $120^{\circ} \mathrm{C}$.

\section{Sterilization control}

Ten samples were randomly chosen and filled with sterilized Ringer solution. Then, the absorbent paper points were removed from contact with root canal walls after 15 seconds and individually transported to a plastic micro-tube (GenuineAxygenQuality, CA, USA) containing $1 \mathrm{~mL}$ of $0.9 \%$ saline solution (Basso, Caxias do Sul, RS, Brazil). The material was homogenized and after five minutes an aliquot of $100 \mu \mathrm{L}$ of saline solution was cultivated on blood agar with the aid of a Drigalski handle, in duplicate. The samples were incubated at $37^{\circ} \mathrm{C}$ for 48 hours, in order to verify the bacterial growith.

\section{Inoculum preparation and root canal contamination}

In an essay tube containing $5 \mathrm{~mL}$ of Tryptic Soy Broth (TSB, Merck, Frankfurt, Germany) $10 \mu \mathrm{L}$ of the culture of $E$. faecalis (ATCC29212) were inoculated. The tube was incubated at $37^{\circ} \mathrm{C}$ for 24 hours in an incubator. The turbidity level of inoculum was adjusted according to grade 1.0 into the McFarland scale $^{6}$, using Tryptic Soy Broth.

In each one of the 120 samples previously sterilized, $0.8 \mathrm{~mL}$ of the inoculum containing $E$. faeca- 
lis was inoculated inside the root canal until total filling, using disposable syringes (Med-Inject, São José, SC, Brazil). Then, a new culture with equal turbidity was injected into the root canal every 24 hours for a period of 14 days. After each renewal, the samples were stored at $37^{\circ} \mathrm{C}$ in an incubator in order to promote biofilm formation.

\section{Contamination control}

Twenty samples were randomly chosen for contamination control. Sterilized paper points \#25 were inserted into the root canal of each sample for a period of 15 seconds. After that, the paper point was placed into the Eurotype tubes containing $1 \mathrm{ml}$ of $0.9 \%$ saline solution, sonicated for 20 seconds. Serial dilutions at $10^{-4}$ were performed. From the diluted sample, an aliquot of $25 \mu \mathrm{L}$ was cultivated in plates containing Agar Plate Count Agar (AES, Combourg, France) with the aid of a Drigalski handle in duplicate. The plates were incubated at $37^{\circ} \mathrm{C}$ for 24 hours in an incubator. Catalase and oxidase tests (Newprov, Pinhais, PR, Brazil), and Gram coloration were performed in order to evaluate the morpho-tinctorial characterization of colonies of $E$. faecalis.

\section{Classification of treatment groups}

The 120 samples were randomly divided into six groups $(n=20)$ according to the chemical auxiliary substance used in the chemo-mechanical preparation, as well as the use of high-power diode laser, as showed in Table 1.

Table 1 - Groups distribution according to the chemical auxiliary substance used in the chemo-mechanical preparation and to the use or not of the high-power diode laser

\begin{tabular}{|c|c|c|c|c|}
\hline Group & $\mathrm{N}$ & $\begin{array}{c}\text { Chemo-mechanical } \\
\text { preparation }\end{array}$ & Chemical auxiliary substance & Laser diode \\
\hline $\mathrm{G} 1(\mathrm{NaOCl})$ & 20 & Yes & $2.5 \%$ sodium hypochlorite ${ }^{*}$ & No \\
\hline $\mathrm{G} 2(\mathrm{CHX})$ & 20 & Yes & $2.0 \%$ chlorhexidine gel ${ }^{* *}$ & No \\
\hline $\mathrm{G} 3(\mathrm{NaOCl}+\mathrm{DL})$ & 20 & Yes & $2.5 \%$ sodium hypochlorite & Yes \\
\hline $\mathrm{G} 4(\mathrm{CHX}+\mathrm{DL})$ & 20 & Yes & $2.0 \%$ chlorhexidine gel $^{* *}$ & Yes \\
\hline $\mathrm{G} 5(\mathrm{NaCl}+\mathrm{DL})$ & 20 & Yes & $0.9 \%$ saline solution ${ }^{* * *}$ & Yes \\
\hline G6 (no treatment) & 20 & No & None & No \\
\hline Total & 120 & & & \\
\hline
\end{tabular}

(Lírio Química Ltda, São Vicente, SP, Brazil)

* (Essencial Pharma, Itapetininga, SP, Brazil)

(Basso, Caxias do Sul, RS, Brazil)

\section{Root canal preparation and laser application}

The working length was established by introducing a K-file \#10 into the root canal until its tip was visualized at the apical foramen. The working length was established by reducing $1 \mathrm{~mm}$ from this measure. The root canals were prepared by the crown-down technique, adopting the following sequence of instruments: Sx, F2 and F3 files of ProTaper rotary system (Dentsply-Maillefer, Ballaigues, Switzerland), followed by K-files \#35 and \#40. The rotary files were activated by X-Smart Endodontic Motor (Dentsply-Maillefer, Ballaigues, Switzerland), with $300 \mathrm{RPM}$ of speed and $2 \mathrm{~N} / \mathrm{cm}^{2}$ of torque.

In the $\mathrm{G} 1(\mathrm{NaOCl})$ and $\mathrm{G} 3(\mathrm{NaOCl}+\mathrm{DL}), 2.5 \%$ sodium hypochlorite was used as chemical auxiliary substance in the root canal preparation. The root canal was filled with this solution and irrigation with $4 \mathrm{ml}$ of the same substance was performed after the action of each instrument. In the G2(CHX) and G4(CHX+DL), 2,0\% chlorhexidine gel (Essencial Pharma, Itapetininga, SP, Brazil) was used as auxiliary chemical substance. The root canal was filled with this substance and irrigation with $4 \mathrm{ml}$ of
$0.9 \%$ saline solution was performed after the action of each instrument. In the $\mathrm{G} 5(\mathrm{NaCl}+\mathrm{DL}), 0.9 \%$ saline solution was used as chemical auxiliary substance in the root canal preparation. The root canal was filled with this solution and irrigation with $4 \mathrm{~mL}$ of the same substance was performed after the action of each instrument. After the action of the last file, irrigation with $5 \mathrm{ml}$ of $17 \%$ EDTA (Iodontosul, Porto Alegre, RS, Brazil) was performed, followed by irrigation with $5 \mathrm{~mL}$ of $0.9 \%$ saline solution. Then, the root canals were dried with sterilized absorbent paper points.

After the chemo-mechanical preparation, the samples of $\mathrm{G} 3(\mathrm{NaOCl}+\mathrm{DL})$ and $\mathrm{G} 4(\mathrm{CHX}+\mathrm{DL})$, were irradiated with a diode laser (Opus 10, OpusDent, Sharplan Laser Industries, Ltd., Tel-Aviv, Israel), with a total power of $3 \mathrm{~W}$ and $830 \mathrm{~nm}$ of wavelength. The helical movement technique developed by Gutknecht et al. ${ }^{13}$ (1996) was performed in these groups. The optic fiber was placed $1 \mathrm{~mm}$ short of working length and removed with $2 \mathrm{~mm} / \mathrm{s}$ of speed, in helical movements, in an apical-coronal direction, for 6 seconds in each application. Four cycles of irradiation were performed with an interval of 10 seconds between each application. 


\section{Microbiological analysis}

After laser application, the root canal was immediately filled with sterilized Ringer solution. Sterilized absorbent paper points were inserted into the root canal at working length. Then, the absorbent paper points were removed from contact with the root canal walls after 15 seconds and individually transported to a plastic micro-tube (GenuineAxygenQuality, CA, USA) containing $1 \mathrm{~mL}$ of $0.9 \%$ saline solution. The content was homogenized and diluted to $10^{-3}$. Aliquots of $100 \mu \mathrm{L}$ of the dilution were cultivated on the surface of the blood agar, in duplicate, with the aid of a Drigalski handle, being incubated for 18 to 24 hours at $37^{\circ} \mathrm{C}$. After the incubation period, the counting of the number of colony-forming units of the plates was performed.

\section{Data analysis}

In the microbiology analysis, all data were log transformed. One-way ANOVA was applied on these data followed by Tukey's post hoc procedure. The level of significance was set at $\alpha=0.05$. Data were analyzed using SPSS version 17.0.

\section{Results}

The results of microbiological analysis are expressed in the Table 2. G6 (no treatment) showed an average count of $2.43 \log _{10} \mathrm{CFU} / \mathrm{mL}$, being statistically different from all other groups $(p<0.05)$. There was no statistically significant difference between $\mathrm{G} 1(\mathrm{NaOCl}), \mathrm{G} 2(\mathrm{CHX}), \mathrm{G} 3(\mathrm{NaOCl}+\mathrm{DL})$ and $\mathrm{G} 4(\mathrm{CHX}+\mathrm{DL})$. However, these groups were statistically different when compared to $\mathrm{G} 5(\mathrm{NaCl}+\mathrm{DL})$, showing lower values of counting of the number of colony-forming units $(\mathrm{p}<0.05)$.

Table 2 - Mean and standard deviation of CFU/mL ( $\left.\log _{10}\right)$ of each group, and microbial reduction (\%) of each group compared to G6 (no treatment).

\begin{tabular}{l|c|c}
\multicolumn{1}{c|}{ Group } & CFU/mL $\left(\log _{10}\right)$ & Microbial reduction (\%) \\
\hline G1 $(\mathrm{NaOCl})$ & $1.25^{\mathrm{A}} \pm 0,45$ & 89.82 \\
$\mathrm{G} 2(\mathrm{CHX})$ & $1.36^{\mathrm{A}} \pm 0,53$ & 81.86 \\
$\mathrm{G} 3(\mathrm{NaOCl}+\mathrm{DL})$ & $1.04^{\mathrm{A}} \pm 0,13$ & 99.42 \\
$\mathrm{G} 4(\mathrm{CHX}+\mathrm{DL})$ & $1.18^{\mathrm{A}} \pm 0,37$ & 93.48 \\
$\mathrm{G} 5(\mathrm{NaCl}+\mathrm{DL})$ & $1.78^{\mathrm{B}} \pm 0,48$ & 65.40 \\
$\mathrm{G} 6$ (no treatment) & $2.43^{\mathrm{C}} \pm 0,11$ & - \\
\hline
\end{tabular}

Different letters indicate a statistically significant difference at the $5 \%$ level.

\section{Discussion}

One of the most important factors for achieving endodontic success is an effective decontamination of root canal system. Chemical substances and alternative resources are available to perform this role concurrently with mechanical action of endodontic instruments.

The model of biofilm formation used in this study simulates the clinical conditions found in infected root canals. Enterococcus faecalis is usually found in persistent lesions even after root canal treatment ${ }^{14-16}$. Furthermore, this microorganism shows the ability to successfully colonize the root canal system in the biofilm form ${ }^{3,17}$, which justifies its selection for the tested specie of the present study.

Nowadays, endodontic studies are searching for effective ways to neutralize microorganisms such as $E$. faecalis from the root canal system. On this way, several laser systems have been tested as adjuncts to currently used disinfection methods in root canal treatment.

In the present study, a high-power diode laser was tested in order to evaluate the additional anti- microbial effects of this alternative resource on root canal system infected with E.faecalis. The high-power lasers have shown to decrease the endodontic microbiota ${ }^{12,18,19}$. In addition, the diode laser is easy to transport and can be considered a more economical alternative when compared to other high-power lasers such as Er,Cr:YSGG, Nd:YAG and $\mathrm{CO}_{2}$. For these reasons, the diode laser was tested as an antimicrobial alternative in the present study, to promote the decontamination of root canal system.

Groups $\mathrm{G} 3(\mathrm{NaOCl}+\mathrm{DL})$ and $\mathrm{G} 4(\mathrm{CHX}+\mathrm{DL})$ showed lower counting of the number of colony-forming units than all other groups, although with no statistically significant difference when compared to $\mathrm{G} 1(\mathrm{NaOCl})$ and $\mathrm{G} 2(\mathrm{CHX})$ where the root canals were not irradiated. Similar results were found in previous studies $^{6,20-22}$ which referred that diode laser helped to reduce the number of bacteria in deep layers of infected root canal system, when associated to conventional chemo-mechanical preparation. This can be explained by the broad antimicrobial spectrum of sodium hypochlorite and chlorhexidine, demonstrated by previous studies ${ }^{23,24}$, as well as to the protein denaturation and photothermal action provided by high-power diode laser over the bacterial cell ${ }^{25}$. 
High-power lasers have been tested as adjuncts to currently used disinfection methods in root canal treatment. However, these lasers may induce thermal injury in tissues, such as dentin carbonization, root ankylosis, cementum melting, root resorption and periradicular necrosis ${ }^{26-29}$. In the present study the irradiation with diode laser was performed through short cycles with an interval of 10 seconds between each application. Thus, there is no increase of temperature on the root canal surface according to previous study ${ }^{13}$.

The results of present study showed that the groups where $2.5 \%$ sodium hypochlorite was used as chemical auxiliary substance demonstrated a lower mean in the counting of CFUs when compared to $2,0 \%$ chlorhexidine gel, regardless of irradiation with diode laser. It can be explained by the lower superficial tension and liquid formulation of sodium hypochlorite, which provides a higher diffusion into root canal system and dentinal tubules.

Sodium hypochlorite is the most common chemical auxiliary substance in the root canal therapy. This substance has effective antimicrobial activity ${ }^{23}$ and ability to dissolve organic tissues ${ }^{30}$. However, is extremely cytotoxic when extravasated to the periapical tissues ${ }^{31}$, promotes dentin deproteination ${ }^{32}$ and interferes negatively on bond strength between restorative material and dentin ${ }^{33}$. Chlorhexidine has been used as an alternative to chemical auxiliary substance in the root canal preparation its broad antimicrobial spectrum ${ }^{26}$ and substantivity ${ }^{34}$. However, this substance is not able to dissolve pulp tissue $^{35}$. According to present study, both chemical auxiliary substances were not able to reduce completely the microorganisms from the root canal system, when used without the aid of diode laser. These findings testify that alternative resources such as high-power diode laser are necessary to improve the decontamination of the root canal system, reaching inaccessible areas by conventional methods of chemo-mechanical preparation.

Despite the effectiveness of tested protocols, none of methods was able to reduce completely the microbial content of root canal system. $\mathrm{G} 3(\mathrm{NaOCl}+\mathrm{DL})$ and $\mathrm{G} 4(\mathrm{CHX}+\mathrm{DL})$ reached $99.42 \%$ and $93.48 \%$ of microbial reduction respectively, being considered the most effective protocols on the decontamination process. However, these protocols were not able to control the infection in an absolute way, even with mechanical action of endodontic instruments, chemical action of chemical auxiliary substance and the association of high-power diode laser. It can be explained by the high resistance of E.faecalis and its organization in a biofilm structure $^{36}$, which can prevent its complete eradication from the root canal system.

The present study suggests the use of high-power diode laser as an adjunct to chemo-mechanical preparation with $2.5 \%$ sodium hypochlorite or $2,0 \%$ chlorhexidine gel. In addition to the chemical action of the auxiliary chemical substance and mechanical action of the endodontic instruments, the high-power diode laser would be an additional resource with ability to reach complexity areas of the root canal system. Therefore, the removal of resistant microorganisms which are commonly found in cases of endodontic infection would be facilitated into the root canal system.

\section{Conclusion}

Under the limitation of this study, it can be concluded that the use of high-power diode laser, when associated to $2.5 \%$ sodium hypochlorite or $2,0 \%$ chlorhexidine gel, improves the antimicrobial effect on root canals infected E.faecalis.

\section{Resumo}

Objetivo: avaliar a ação antibacteriana adicional do laser diodo de alta potência após o uso de hipoclorito de sódio 2,5\% e clorexidina gel 2,0\% em canais radiculares infectados com Enterococcus faecalis. Materiais e método: cento e vinte dentes humanos unirradiculares foram inoculados com Enterococcus faecalis por 14 dias e divididos aleatoriamente em 6 grupos $(n=20)$, de acordo com a substância química auxiliar utilizada no preparo químico-mecânico e o uso do laser diodo de alta potência: G1(NaOCl) - PQM com hipoclorito de sódio 2,5\%; G2(CHX) - PQM com clorexidina gel 2,0\%; G3 ( NaOCl+DL) - PQM com hipoclorito de sódio 2,5\% + aplicação de laser diodo; $G 4(C H X+D L)$ - PQM com clorexidina gel 2,0\% + aplicação de laser diodo; 65 ( $\mathrm{NaCl}+\mathrm{DL})$ - PQM com soro fisiológico 0,9\% + aplicação de laser diodo; G6 (sem tratamento) - nenhum procedimento foi realizado. Teste microbiológico (contagem de UFCs) foi realizado para avaliar a eficácia dos tratamentos propostos. Os dados foram submetidos à análise estatística através de One-way ANOVA seguido por post-hoc de Tukey $(\alpha=0,05)$. Resultados: G3( $\mathrm{NaOCl}+\mathrm{DL})$ teve redução de $99,42 \%$ de Enterococcus faecalis, seguido por $\mathrm{G} 4(\mathrm{CHX}+\mathrm{DL})$ 93,48\%; G1(NaOCl) - 89,82\%; G2(CHX) - 81,86\%; G5(NaCl+DL) - 65,40\%; and G6(sem tratamento) - sem redução. Houve diferença estatisticamente significante na contagem de UFCs de todos os grupos em relação ao grupo 6 (sem tratamento) (p<0,05). G1(NaOCl), G2 $(\mathrm{CHX}), \quad G 3(\mathrm{NaOCl}+\mathrm{DL})$ e $G 4(\mathrm{CHX}+\mathrm{DL})$ foram superiores ao grupo $G 5(\mathrm{NaCl}+D L)(p<0,05)$. Conclusão: Laser diodo de alta potência, quando associado ao NaOCl 2,5\% ou clorexidina gel 2,0\% aumenta o efeito antimicrobiano destas substäncias nos canais radiculares infectados com E. Faecalis.

Palavras-chave: Laser. Hipoclorito de sódio. Clorexidina. Enterococcus faecalis. 


\section{References}

1. Sundqvist G, Figdor D, Persson S, Sjögren U. Microbiologic analysis of teeth with failed endodontic treatment and the outcome of conservative re-treatment. Oral Surg Oral Med Oral Pathol Oral Radiol Endod 1998;85:86-93.

2. Nair PN. Light and electron microscopic studies of root canal flora and periapical lesions. J Endod 1987;13:29-39.

3. Sedgley CM, Lennan SL, Appelbe OK. Survival of Enterococcus faecalis in root canals ex vivo. Int Endod $\mathrm{J}$ 2005;38:735-4.

4. Körstgens V, Flemming HC, Wingender J, Borchard W. Uniaxial compression measurement device for investigation of the mechanical stability of biofilms. J Microbiol Methods 2001;46:9-17.

5. Ariaz-MolizMT,Ferrer-Luque CM, González-Rodríguez MP, Valderrama MJ, Baca P. Eradication of Enterococcus faecalis biofilms by cetrimide and chlorhexidine. J Endod 2010;36:87-90.

6. Souza EB, Cai S, Simionato MR, Lage-Marques JL. High-power diode laser in the disinfection in depth of the root canal dentin. Oral Surg Oral Med Oral Pathol Oral Radiol Endod 2008;106:68-72.

7. Haapasalo M, Orstavik D. In vitro infection and desinfection of dentinal tubules. J Dent Res 1987;66:1375-9.

8. Marchesan MA, Brugnera-Junior A, Ozorio JE, Pécora JD, Sousa-Neto MD. Effect of 980-nanometer diode laser on root canal permeability after dentin treatment with different chemical solutions. J Endod 2008;34:721-4.

9. Souza LC, Brito PR, Oliveira JC, Alves FR, Moreira EJ, Sampaio-Filho HR et al. Photodynamic therapy with two different photosensitizers as a supplement to instrumentation/irrigation procedures in promoting intracanal reduction of Enterococcus faecalis. J Endod 2010;36:292-6.

10. Garcez AS, Nuñez SC, Hamblim MR, Suzuki H, Ribeiro MS. Photodynamic therapy associated with conventional endodontic treatment in patients with antibiotic-resistant microflora: a preliminary report. J Endod 2010;36:1463-6.

11. Rios A, He J, Glickman GN, Spears R, Schneiderman ED, Honeyman AL. Evaluation of photodynamic therapy using a light-emitting diode lamp against Enterococcus faecalis in extracted human teeth. J Endod 2011;37:856-9.

12. Dewsnup N, Pileggi R, Haddix J, Nair U, Walker C, Varella $\mathrm{CH}$. Comparison of bacterial reduction in straight and curved canals using erbium, chromium: yttrium-scandium-gallium-garnet laser treatment versus a traditional irrigation technique with sodium hypochlorite. J Endod 2010;36:725-8.

13. Gutknecht N, Kaiser F, Hassan A, Lampert F. Long-term clinical evaluation of endodontically treated teeth by Nd:YAG lasers. J Clin Laser Med Surg 1996;14:7-11.

14. Roças IN, Siqueira JF Jr, Santos KR. Association of Enterococcus faecalis with different forms of periradicular diseases. J Endod 2004;30:315-20.

15. Siqueira, JF Jr., Rôças IN. Polymerase chain reaction-based analysis of microorganisms associated with failed endodontic treatment. Oral Surg Oral Med Oral Pathol Oral Radiol Endod 2004;97:85-94.

16. Subramanian K, Mickel A K. Molecular Analyses of Persistent Periradicular Lesions and Root Ends Reveals a Diverse Microbial Profile. J Endod 2009;35:950-7.
17. George S, Kishen A, Song KP. The role of environmental changes on monospecies biofilm formation on root canal wall by Enterococcus faecalis. J Endod 2005;31:867-72.

18. Wang QQ, Zhang CF, Yin XZ. Evaluation of the bactericidal effect of Er,Cr:YSGG, and Nd:YAG lasers in experimentally infected root canals. J Endod 2007;33:830-2.

19. Meire MA, De Prijck K, Coenye T, Nelis HJ, De Moor RJ. Effectiveness of different laser systems to kill Enterococcus faecalis in aqueous suspension and in an infected tooth model. Int Endod J 2009;42:351-9.

20. Lim Z, Cheng JL, Lim TW, Teo EG, Wong J, George S et al. Light activated disinfection: an alternative endodontic disinfection strategy. Aust Dent J 2009;54:108-14.

21. Mehrvarzfar P, Saghiri MA, Asatourian A, Fekrazad R, Karamifar K, Eslami G, et al. Additive effect of a diode laser on the antibacterial activity of $2.5 \% \mathrm{NaOCl}, 2 \% \mathrm{CHX}$ and MTAD against Enterococcus faecalis contaminating root canals: an in vitro study. J Oral Sci 2011;53:355-60.

22. Preethee T, Kandaswamy D, Arathi G, Hannah R. Bactericidal effect of the $908 \mathrm{~nm}$ diode laser on Enterococcus faecalis in infected root canals. J Conserv Dent 2012;15:46-50.

23. Krause TA, Liewehr FR, Hahn CL. The antimicrobial effect of MTAD, sodium hypochlorite, doxycycline, and citric acid on Enterococcus faecalis. J Endod 2007;33:28-30.

24. Ferraz CC, Gomes BP, Zaia AA, Teixeira FB, Souza-Filho FJ. In vitro assessment of the antimicrobial action and the mechanical ability of chlorhexidine gel as an endodontic irrigant. J Endod. 2001;27:452-5.

25. Gutknecht N, Moritz A, Conrads G, Sievert T, Lampert F. Bactericidal effect of the Nd: YAG laser in vitro root canal. J Clin Laser Med Surg1996;14:77-80.

26. Nunes MR, Mello I, Franco GC, Medeiros JM, Santos SS, Habitante SM et al. Effectiveness of photodynamic therapy against Enterococcus faecalis, with and without the use of an intracanal optical fiber: an in vitro study. Photomed Laser Surg 2011;29:803-8.

27. Schoop U, Kluger W, Moritz A, Nedjelik N, Georgopoulos A, Sperr W. Bactericidal effect of different laser systems in the deep layers of dentin. Lasers Surg 2004;35:111-6.

28. Bahcall J, Howard P, Miserendino L, Walia H. Preliminary investigation of the histological effects of laser endodontic treatment on the periradicular tissues in dogs. J Endod 1992;18: 47-51.

29. Depraet FJ, De Bruyne MA, De Moor RJ. The sealing ability of an epoxy resin root canal sealer after Nd:YAG laser irradiation of the root canal. Int Endod J 2005;38:302-9.

30. Zehnder M, Grawehr M, Hasselgren G, Waltimo T. Tissue-dissolution capacity and dentin-disinfecting potential of calcium hydroxide mixed with irrigating solutions. Oral Surg Oral Med Oral Pathol Oral Radiol Endod 2003;96:608-13.

31. Chang YC, Huang FM, Tai KW, Chou MY. The effect of sodium hypochlorite and chlorhexidine on cultured human periodontal ligament cells. Oral Surg Oral Med Oral Pathol Oral Radiol Endod 2001;92:446-50.

32. Di Renzo M, Ellis TH, Sacher E, Stangel I. A photoacoustic FTIRS study of the chemical modifications of human dentin surfaces: II. Deproteination. Biomaterials 2001;22:793-7.

33. Farina AP, Cecchin D, Barbizam JV, Carlini-Júnior B. Influence of endodontic irrigants on bond strength of a self-etching adhesive. Aust Endod J 2011;37:26-30. 
34. Carrilho MR, Carvalho RM, Sousa EN, Nicolau J, Breschi L, Mazzoni A, et al. Substantivity of chlorhexidine to human dentin. Dent Mater 2010;26:779-85.

35. Okino LA, Siqueira EL, Santos M, Bombana AC, Figueiredo JA. Dissolution of pulp tissue by aqueous solution of chlorhexidine digluconate and chlorhexidine digluconate gel. Int Endod J 2004;37:38-41.

36. Estrela C, Sydney GB, Figueiredo JAP, Estrela CRA. A Model System to Study Antimicrobial Strategies in Endodontic Biofilms. J Appl Oral Sci. 2009;17:87-91.

\section{Corresponding author:}

Matheus Albino Souza

Post-Graduate Program in Dentistry - University of Passo Fundo.

BR 285/São José.

99052-900 - Passo Fundo - RS - Brazil

Telephone: +55 54 3316-8100.

E-mail: matheus292@yahoo.com.br

Recebido: 14/08/2013. Aceito: 25/02/2014. 